\title{
Measurement of Radon Activity in Soil Gas and the Geogenic Radon Potential Mapping Using RAD7 at Al-Tuwaitha Nuclear Site and the Surrounding Areas
}

\author{
Yousif Muhsin Zayir Al-bakhat ${ }^{1}$, Nidhala Hassan Kazem Al-ANI ${ }^{2}$, \\ Batool Fayidh Mohammed ${ }^{2}$, Nabeel Hashem Ameen ${ }^{1}$, Zainab Abdul-Zahra Jabr', \\ Saliha Husayn Hammid ${ }^{1}$ \\ ${ }^{1}$ Radiation and Nuclear Safety Directorate (RNSD), Ministry of Science and Technology (MOST), Baghdad, Iraq \\ ${ }^{2}$ Department of Physics, University of Baghdad, Baghdad, Iraq
}

Email address:

yousif_zayir@yahoo.com (Y.M. Z. Al-bakhat), Batool.faydh@yahoo.com (B. F. Mohammed),

nabeelhameen@googlemail.com (N. H. Ameen)

\section{To cite this article:}

Yousif Muhsin Zayir Al-bakhat, Nidhala Hassan Kazem Al-ANI, Batool Fayidh Mohammed, Nabeel Hashem Ameen, Zainab Abdul-Zahra Jabr, Saliha Husayn Hammid. Measurement of Radon Activity in Soil Gas and the Geogenic Radon Potential Mapping Using RAD7 at Al-Tuwaitha Nuclear Site and the Surrounding Areas. Radiation Science and Technology. Vol. 3, No. 3, 2017 , pp. $29-34$. doi: $10.11648 /$ j.rst.20170303.13

Received: April 25, 2017; Accepted: May 9, 2017; Published: May 19, 2017

\begin{abstract}
In this study Soil gas radon ${ }^{222} \mathrm{Rn}$ activity was measured in different locations at Al-Tuwaitha Nuclear Site and the surrounding areas using RAD7 (radon detector). Radon activity in the soil gas varied from $(866 \pm 150$ to $16004 \pm 521) \mathrm{Bq} / \mathrm{m}^{3}$ near Alaibtihal School and Ishtar $\backslash$ Al-Ttakhi School respectively. These concentrations values are well below the allowed levels that range from $(0.4$ to 40$) \mathrm{KBq} / \mathrm{m}^{3}$. The annual effective doses related to the inhalation of radon gas and its progeny which were calculated from the Concentration of emanation in air near ground ranged from $(0.0082305$ to 0.152102$) \mathrm{mSv} / \mathrm{y}$. these results are less than the recommended global average dose from the inhalation of radon from all sources, which is 1 $\mathrm{mSv} / \mathrm{y}$. The Health risks originating from indoor radon concentration can be attributed to natural factors and is characterized by geogenic radon potential (GRP), The highest values were found in Ishtar $\backslash$ Al-Ttakhi school which is (16.004) and The lowest values were found Near Alaibtihal school which is (0.288666667), the lowest value according to Neznal was classified as low $($ GRP $<10)$ and the highest value was classified as medium $(10<$ GRP $<35)$, according to Barnet and Pacherová low GRP causes $<230 \mathrm{~Bq} \mathrm{~m}^{-3}$ while medium GRP causes $230-460 \mathrm{~Bq} \mathrm{~m}^{-3}$ indoor radon concentration. From these different values of GRP a geogenic radon risk map was created, which assists human health risk assessment and risk reduction since it indicates the potential of the source of indoor radon. The results from this study shows that the region has background radioactivity levels within the natural limits.
\end{abstract}

Keywords: Radon Gas, Al Tuwaitha Nuclear Site, RAD7

\section{Introduction}

In the environment, the fundamental normal source of uranium, and also of whatever other antecedent of one of the radon isotopes, is probably going to be the resuspension of tidy particles from the earth. Radon-222 exhalation starting from the earliest stage the principle wellspring of $210 \mathrm{~Pb}$ in the air. Radon isotopes of natural origin are, separately, 222Rn (half-life $\mathrm{t} 1 / 2=3.8$ day), $220 \mathrm{Rn}(\mathrm{t} 1 / 2=55.6 \mathrm{~s})$ and 219Rn (t1/2 = $3.96 \mathrm{~s})$ [1] Radon is a noble gas with slight ability to form compounds under lab conditions. The density of radon is $9.73 \mathrm{~g} / 1$ at ${ }^{\circ} \mathrm{C}$ [2].

As radon experiences radioactive decay, it emits radiation and turns into another radioactive component. This is rehashed a few times until it ends up plainly stable lead. The components that radon changes into are called radon daughters or radon descendants [3]. The major radioactive exposure of public health concern is inhalation of short-lived decay products (218Po and 214Po) of 222Rn [4]. Alpha particles released by these two radioisotopes, convey to target 
cells in the respiratory epithelium the energy that is considered to bring about radon-related lung-disease [5].

The original source of radon-222 is from the common radioactive decay of uranium-238 and radium-226. Certain soils and rocks that contain elevated amounts of uranium likewise store regular deposits of radon: granite, phosphate, shale, pitchblende [10]. The lower air pressure indoors gives rise to a pressure-driven flow of radon-rich soil air into the indoor environment through cracks in the bottom slab and cellar walls [11].

Radon particles situated inside solid grains are probably not going to end up noticeably accessible for discharge to the air, owing to their very low diffusion coefficients in solids. However, if they are located in the interstitial space between grains, they may diffuse to the surface. In this way, releases of radon from residue repository to the environment happen by the accompanying arrangement of procedures [12]:

(a) Emanation - radon atoms formed from the decay of radium escape from the grains (mainly because of recoil) into the interstitial space between the grains.

(b) Transport - diffusion and advective flow cause the movement of the emanated radon atoms through the residue or soil profile to the ground surface.

(c) Exhalation - radon atoms that have been transported to the ground surface and then exhaled to the atmosphere.

\section{Areas of the Study}

Al Tuwaitha Nuclear site filled in as the establishment of Iraq's atomic innovative work from 1967 until its closure in 2003 [6]. Al-Tuwaitha Nuclear site is the biggest, most complex and most radiological contaminated site in Iraq [7]. Substantial amounts of radioactive materials and waste related with Iraq's previous atomic facilities at Al Tuwaitha nuclear site and in addition other nuclear facilities may represent a noteworthy wellbeing and security risk to workers and inhabitants of the surrounding communities and to the earth. About the greater part of Iraq's previous atomic facilities were harmed and are presently either known to be, or are conceivably, radioactively contaminated. These nuclear facilities are all hazardous in some fashion and need disassembly and disposal, so to bolster the Government of Iraq in the assessment and decommissioning of past facilities that utilized radioactive resources, The International Atomic Energy Agency (IAEA) Board of Governors has accepted such project [8].

Twenty locations have been chosen at Al-Tuwaitha Nuclear Site and some surrounding locations also selected to be the areas of the current study to make sure that all the selected locations are safe and doesn't cause any hazards on the employees these locations varied between Administrative buildings, radiological laboratories, radiological storages and houses as shown in figure 1.

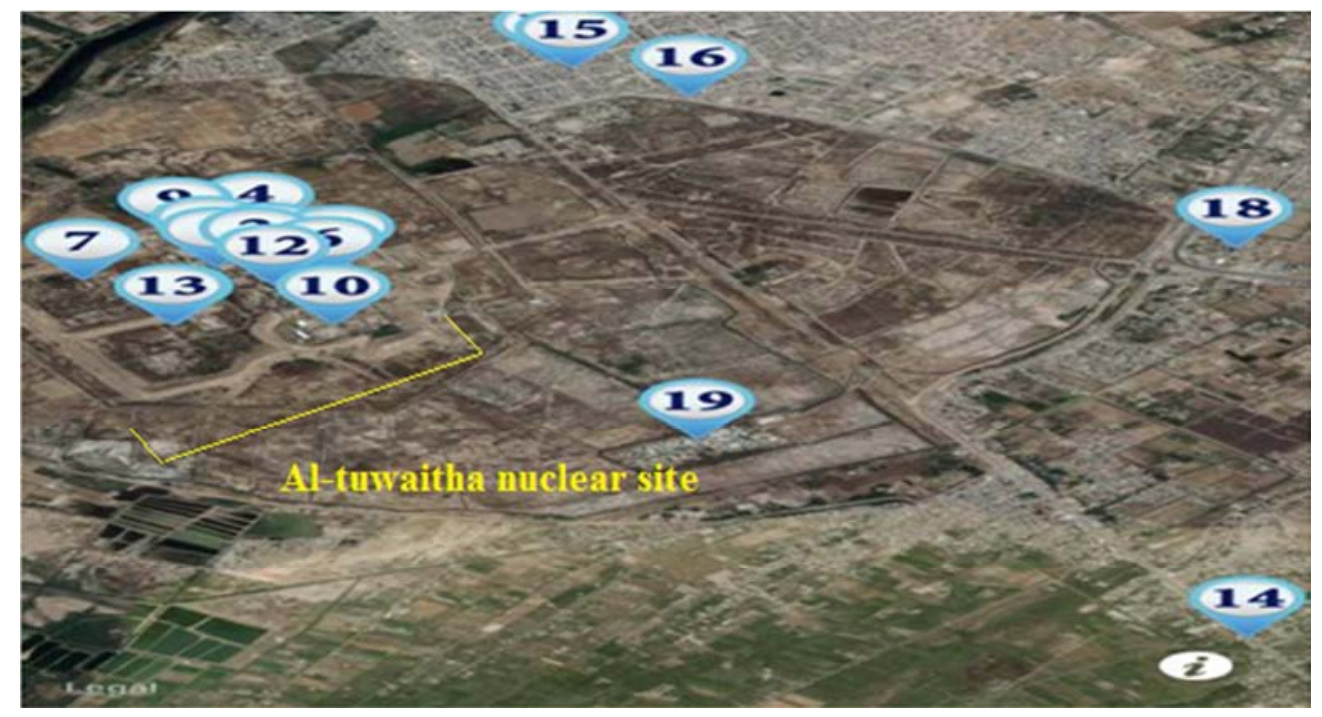

Figure 1. A photo of Al-Tuwaitha Nuclear Site and some surrounding locations shows radon monitoring points.

\section{Airborne Radon Measurement}

Radon activity concentration was measured in twenty locations at Al-Tuwaitha nuclear site and some surrounding locations using RAD7. RAD7 is continual radon measuring device from Durridge Company (USA). The RAD7 is a Sniffer that uses the 3-minute alpha decay of a radon descendant, without intrusion from other radiations, and the instantaneous alpha decay of a thoron daughter. The RAD-7 uses silicon as a semiconductor material which converts the energy of $\alpha$-particles directly into electrical signals. The measuring range is between 4 to $750000 \mathrm{~Bq} \mathrm{~m}^{-3}$. When the radon and thoron daughters deposited on the surface of the detector they decay and emits alpha particles of characteristic energy directly into the solid-state detector. The RAD7's microprocessor picks up the signal and stores it according to the energy of the particle. When many signals accumulate, they result in a spectrum. The RAD7 groups the spectrum's 200 channels into 8 separate "windows" or energy ranges.

The soil gas radon concentration was measured at a depth 
of $60 \mathrm{~cm}$ using a probe having diameter of $10 \mathrm{~mm}$. The soil probe is immersed in the soil with gentle strokes of hammer. The soil probe is connected to drierite which is connected to the RAD-7 as shown in figure 2. In each measurement we have to keep the moisture under $10 \%$ by using the Drierite desiccant which is an important accessory which absorbs the moisture from the soil gas.

The RAD-7 can measure Radon via 9 different protocol. The protocol have been used for the soil-gas measurements is called the Grab sample protocol. The RAD-7 pumps the soil- gas for 5 minutes into the cell of the detector, and then waits for 5 minutes and count only for 5 minutes. 218Po has a halflife of $3.05 \mathrm{~min}$ and it takes about 3-5 half-lives for the 218Po activity to reach secular equilibrium, hence, in about 9-15 minutes. The decays of the $218 \mathrm{Po}$ would then be counted after 10 mins $(5 \mathrm{~min}$ of pumping plus $5 \mathrm{~min}$ of waiting), in which time $95 \%$ of equilibrium would have been reached [9]. Finally, each set of readings includes four 5- min cycles that at last takes $30 \mathrm{~min}$.

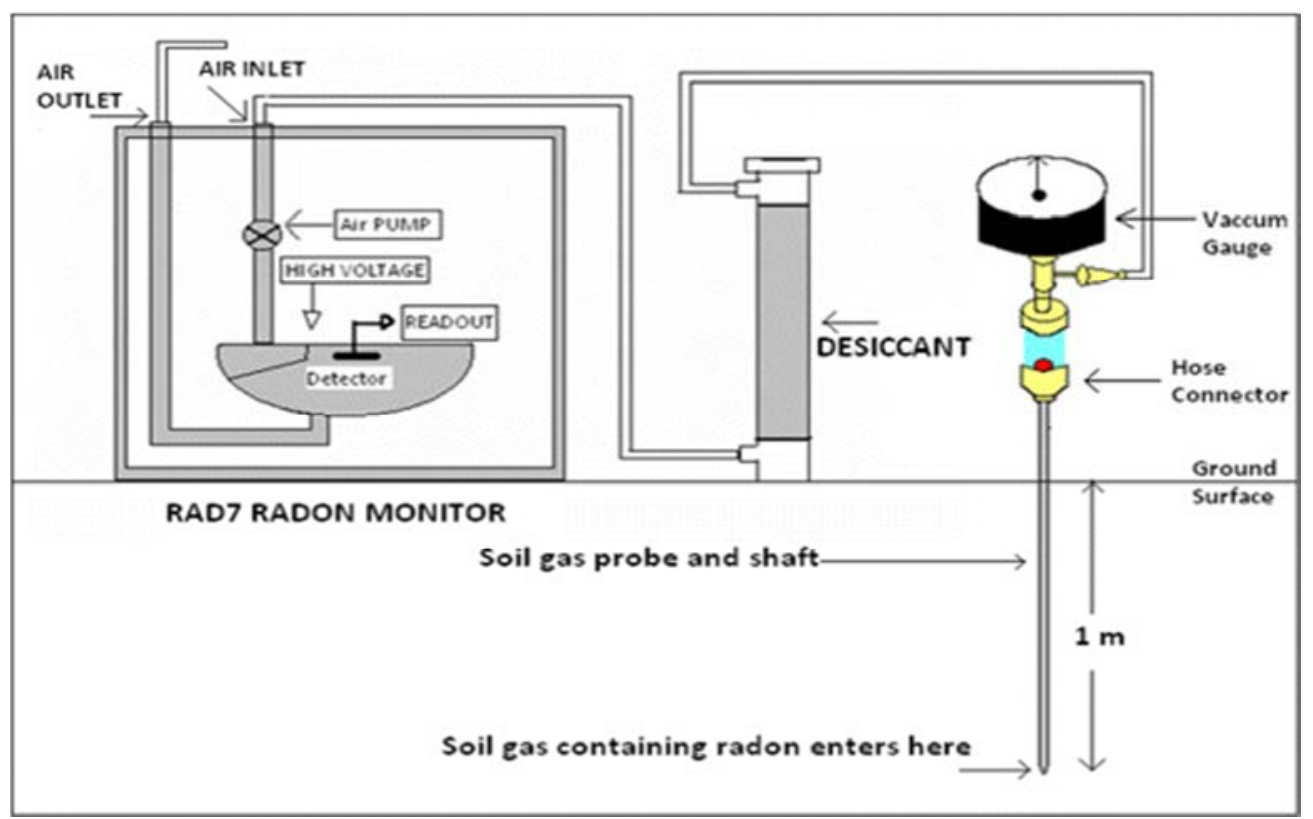

Figure 2. The schematic diagram of the RAD7 soil-gas setup [9].

\section{Estimation the Outdoor Radon Activity and Annual Effective Dose}

Let $\left(\mathrm{C}_{\mathrm{so}}\right)$ be the concentration of emanation in the soil air $\left(\mathrm{Bq} / \mathrm{m}^{3}\right)$, d its diffusion constant $\left(\mathrm{cm}^{2} / \mathrm{s}\right)$, (a) its rate of production within the soil $\left(\mathrm{Bq} / \mathrm{m}^{3}\right)$, which is assumed to be independent of depth and $\lambda$ the radon Decay rate of Emanation which is $\left(2.1 * 10^{-6}\right)$. If the soil is sufficiently porous, diffusion proceeds as if the soil are absent. From the rate of production we can find the concentration of emanation in undisturbed soil air in deeper layers [13]:

$$
\mathrm{C}_{\text {so }}=\frac{\mathrm{a}}{\lambda}
$$

And the exhalation rate $(\mathrm{E})$ is $[13]$ :

$$
E=a \sqrt{\frac{d}{\lambda}}
$$

The constants $\mathrm{d}$ and $\lambda$ are fixed, $\mathrm{d}=0.05 \mathrm{~cm}^{2} / \mathrm{sec}$. Only a fraction of the equilibrium production of emanation escapes into the soil prior to decay within the soil particles, this fraction is found to be $10 \%$. The concentration of emanation at the ground is given by [13].

$$
\mathrm{C}_{\mathrm{ao}}=\mathrm{C}_{\mathrm{so}} \sqrt{\frac{\mathrm{d}}{\mathrm{D}}}
$$

Where $\mathrm{D}$ is the eddy diffusion coefficient $\left(5 * 10^{4} \mathrm{~cm}^{2} / \mathrm{s}\right)$.

For the estimation of average annual effective dose, AED $(\mathrm{mSv} / \mathrm{y})$ received by the public and workers of the studied area due to the outdoor radon and its progeny, Equation (4) was used for the calculation [19]:

$$
A E D\left(\frac{m S v}{y}\right)=C_{R n} * F * O *(D C F)
$$

Where the: AED: The annual effective dose, $C_{\mathrm{Rn}}$ : the activity of outdoor radon in $\mathrm{Bq} / \mathrm{m}^{3}, \mathrm{~F}$ : The global average (0.6) of equilibrium factor for outdoor radon and its descendant, O: The global average outdoor occupancy factor $(1760 \mathrm{~h} / \mathrm{y}), \mathrm{DCF}$ : The dose conversion factor $(9 \mathrm{nSv} / \mathrm{h}$ per $\mathrm{Bq} / \mathrm{m}^{3}$ )

\section{Geogenic and Indoor Radon Map}

Indoor radon concentration are constantly subject to human activity, natural and anthropogenic components, for example, development sorts, building materials, living propensities and meteorology, and are transiently factor and 
characteristic for every specific house. For example, two houses assembled contrastingly on the same land ground will have diverse normal indoor radon concentration, as will two indistinguishably manufactured houses on a similar ground, however with various living propensities for the tenants. As another case, enhancing the protection of a house can impact its indoor radon fixation. In this manner, one is keen on mapping an amount which is nearer to geogenic risk, i.e. which measures 'what earth delivers' as far as radon, on the grounds that for the most part the subsurface (soil gas Radon concentration) is the principle source for indoor radon concentration. It discovers territories, where definite indoor radon estimations are fundamental. Regardless of anthropogenic components and transiently steady over a geographical timescale [14] (see figure 3)

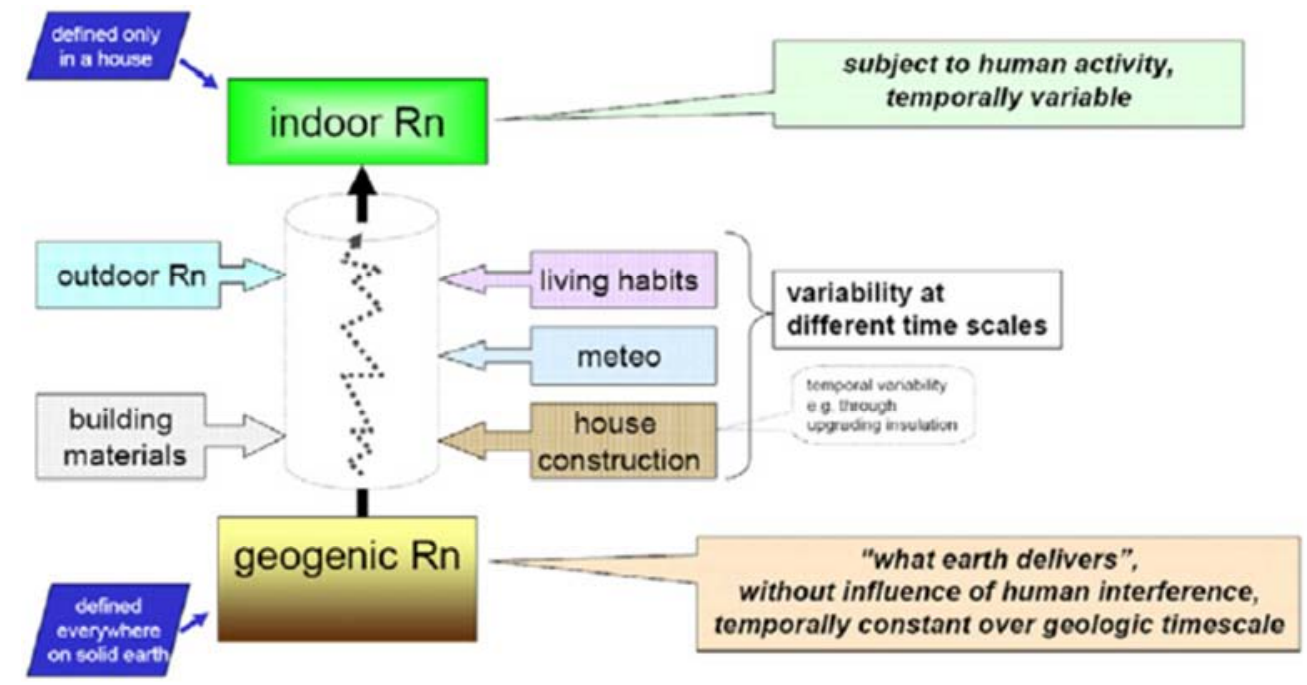

Figure 3. From geogenic radon to indoor radon concentration-influences and definitions [14].

The geogenic map Represent the radon potential at any location in Al-Tuwaitha Nuclear Research Center and some surrounding areas since geogenic radon potential mapping has not been performed there by using soil gas radon measurements with varying permeability of the bare earth. One suggested approach to quantify the geogenic radon potential in order to assist human health risk assessment and risk reduction which developed by Neznal [15].

$$
\mathrm{GRP}=\frac{C}{-\log _{10} k-10}
$$

Where $\mathrm{C}$ is the equilibrium soil gas radon activity concentration at a definite depth $(1 \mathrm{~m})\left(\mathrm{kBq} \mathrm{m}^{-3}\right)$ and $\mathrm{k}$ is the soil gas permeability $\left(\mathrm{m}^{2}\right)$ which we assumed it for bare earth varying from $10^{-11}$ to $10^{-13}(\mathrm{~m} 2)[2]$.

\section{Results and Discussion}

An average value of Radon Activity in $\mathrm{Bq} / \mathrm{m}^{3}$ was measured for each sampling point using RAD7. All the results were listed in Table1.The radioactive level of ${ }^{222} \mathrm{Rn}$ for soil samples ranged from $\left(866 \pm 150 \mathrm{~Bq} / \mathrm{m}^{3}\right)$ in Alaibtihal School to $(16004 \pm 521 \mathrm{~Bq} / \mathrm{m} 3)$ in Ishtar $\backslash \mathrm{Al}$-Ttakhi school at depth $60 \mathrm{~cm}$ under surface These concentrations values are well below the allowed levels which is range $(0.4-40) \mathrm{KBq} / \mathrm{m}^{3}[16,17]$. These values were used to calculate the Rn-222 activity of emanation in air near the ground by using equation (3) with an average value (3897). By using equation (1) we were able to calculate the Production rate (a) of emanation in soil with an average value (0.008629688) and by using equation (2) we calculated the Exhalation rate $(\mathrm{E})$ with an average value (0.012630342).

Table 1. Radon Concentrations in different locations at The Al-Tuwaitha Nuclear site.

\begin{tabular}{|c|c|c|c|c|c|c|c|}
\hline \multirow{2}{*}{$\begin{array}{l}\text { Sample } \\
\text { Point no. }\end{array}$} & \multirow{2}{*}{ Date } & \multirow{2}{*}{ Location } & \multirow{2}{*}{$\begin{array}{l}\text { RAD eye } \\
(\mu \mathrm{Sv} / \mathrm{h})\end{array}$} & \multicolumn{2}{|c|}{ GPS Coordinates } & \multirow{2}{*}{$\begin{array}{l}\text { Air } \\
\text { Temreture }\left({ }^{\circ} \mathrm{C}\right) \\
\end{array}$} & \multirow{2}{*}{$\begin{array}{l}\text { Soil Radon } \\
\text { activity }\left(\mathrm{Bq} / \mathrm{m}^{3}\right)\end{array}$} \\
\hline & & & & $\mathbf{E}$ & $\mathbf{N}$ & & \\
\hline 1 & $2016 / 11 / 1$ & $\begin{array}{l}\text { Near the Radiological and Nuclear Safety } \\
\text { Directorate }\end{array}$ & 0.03 & 44.513587 & 33.206840 & 30.4 & $2060 \pm 648$ \\
\hline 2 & $2016 / 11 / 2$ & Near the Central Laboratories Directorate & 0.03 & 44.512924 & 33.207395 & 27.1 & $3850 \pm 390$ \\
\hline 3 & $2016 / 11 / 3$ & Near the Department of Agriculture & 0.03 & 44.515639 & 33.207224 & 21.3 & $2400 \pm 310$ \\
\hline 4 & $2016 / 11 / 6$ & $\begin{array}{l}\text { Near the Scientific Information Center (Central } \\
\text { Library) }\end{array}$ & 0.04 & 44.515200 & 33.209671 & 23.1 & $1120 \pm 210$ \\
\hline 6 & $2016 / 11 / 23$ & Near The Organization presidency & 0.02 & 44.51777 & 33.20607 & 21.3 & $2650 \pm 310$ \\
\hline 7 & $2016 / 11 / 24$ & Near the Nuclear applications Directorate & 0.04 & 44.50856 & 33.20589 & 15.2 & $1290 \pm 220$ \\
\hline 8 & $2016 / 11 / 27$ & Near The radioisotopes production laboratories & 0.04 & 44.51335 & 33.20780 & 16.4 & $4820 \pm 420$ \\
\hline 9 & $2016 / 11 / 28$ & Between former clinic and design building & 0.04 & 44.51206 & 33.20932 & 17.6 & $7140 \pm 530$ \\
\hline 10 & $2016 / 11 / 29$ & Near the Treatment of Radioactive Waste & 0.04 & 44.518099 & 33.202128 & 23.1 & $6690 \pm 510$ \\
\hline
\end{tabular}




\begin{tabular}{|c|c|c|c|c|c|c|c|}
\hline \multirow{2}{*}{$\begin{array}{l}\text { Sample } \\
\text { Point no. }\end{array}$} & \multirow{2}{*}{ Date } & \multirow{2}{*}{ Location } & \multirow{2}{*}{$\begin{array}{l}\text { RAD eye } \\
(\mu \mathrm{Sv} / \mathrm{h})\end{array}$} & \multicolumn{2}{|c|}{ GPS Coordinates } & \multirow{2}{*}{$\begin{array}{l}\text { Air } \\
\text { Temreture }\left({ }^{\circ} \mathrm{C}\right)\end{array}$} & \multirow{2}{*}{$\begin{array}{l}\text { Soil Radon } \\
\text { activity }\left(\mathrm{Bq} / \mathrm{m}^{3}\right)\end{array}$} \\
\hline & & & & $\mathbf{E}$ & $\mathbf{N}$ & & \\
\hline & & Management & & & & & \\
\hline 11 & $2016 / 12 / 4$ & Near laser building (outside berms) & 0.03 & 44.51205 & 33.202128 & 18.2 & $5970 \pm 460$ \\
\hline 12 & $2017 / 1 / 15$ & The side The Organization presidency & 0.03 & 44.51584 & 33.20542 & 15.5 & $1030 \pm 190$ \\
\hline 13 & $2017 / 1 / 24$ & Near electrical systems & 0.03 & 44.31030 & 33.12489 & 27.2 & $1600 \pm 240$ \\
\hline 14 & $2017 / 2 / 1$ & Alwardia area /aljiearah clinic & 0.02 & 44.55289 & 33.175992 & 17.5 & $2460 \pm 300$ \\
\hline 15 & $2017 / 2 / 6$ & Jisr Diyala $\backslash$ Riyadh & 0.05 & 44.52728 & 33.22343 & 15.7 & $3760 \pm 370$ \\
\hline 16 & $2017 / 2 / 9$ & Jisr Diyala $\backslash$ area of energy storage & 0.02 & 44.53170 & 33.22120 & 17.4 & $6350 \pm 480$ \\
\hline 17 & $2017 / 2 / 26$ & Near alaibtihal school & 0.01 & 44.52646 & 33.22400 & 32.1 & $866 \pm 150$ \\
\hline 18 & $2017 / 2 / 27$ & Jisr Diyala / Al-alearifih & 0.04 & 44.55246 & 33.20847 & 31 & $1240 \pm 200$ \\
\hline 19 & $2017 / 2 / 29$ & Ishtar $\backslash$ alttakhi school & 0.02 & 44.53205 & 33.19251 & 33.5 & $16004 \pm 521$ \\
\hline Min & & & 0.01 & & & 15.2 & $866 \pm 150$ \\
\hline Max & & & 0.05 & & & 33.5 & $16004 \pm 521$ \\
\hline Average & & & 0.03 & & & 22.3 & 3897. \\
\hline
\end{tabular}

The Soil Radon activity values seem to be safe from the point of view of health hazards because as we can see in table 2 the values of the Rn activity of emanation in air near the ground were used to calculate the annual effective dose by using equation (4) and ranged from (0.0082305 to 0.152102) $\mathrm{mSv} / \mathrm{y}$ in Alaibtihal School and Ishtar $\backslash$ Alttakhi School these results are less than the recommended global average dose from the inhalation of radon from all sources, which is 1 $\mathrm{mSv} / \mathrm{y}$. It is worth to mention that variation in soil radon activity during the three months can be attributed to the heterogeneity of uranium / radium distribution and mineralization in the soil / rocks and local permeability of the soil in addition to influence of lithology, soil types and structural attributes (thrusts faults and shears) in the study area. Further, the diffusion of radon through soil are governed by concentration of parent material in soil / rocks, emanation capacity of the ground, porosity of soil and rock, soil moisture because Moisture content is well known to have a strong effect on the emanation coefficient. This is because the typical ranges for recoil in water are much less than in air and therefore water is more effective at stopping radon atoms within the pore space in addition to meteorological parameters (atmospheric pressure, wind speed).

Table 2. The Rn activity of emanation in air near the ground, a, E, AED and GRP in soil.

\begin{tabular}{|c|c|c|c|c|c|c|c|}
\hline \multirow{2}{*}{$\begin{array}{l}\text { Sample } \\
\text { Point no. }\end{array}$} & \multirow{2}{*}{$\begin{array}{l}\text { Production rate (a) } \\
\text { of emanation in soil } \\
\left(\mathrm{Bq} / \mathrm{m}^{3} . \mathbf{s}\right)\end{array}$} & \multirow{2}{*}{$\begin{array}{l}\text { Exhalation rate } \\
\text { (E) }\left(\mathrm{Bq} / \mathrm{m}^{2} . \mathbf{s}\right)\end{array}$} & \multirow{2}{*}{$\begin{array}{l}\text { Rn activity of emanation } \\
\text { in air near the ground } \\
\left(\mathrm{Bq} / \mathrm{m}^{3}\right)\end{array}$} & \multirow{2}{*}{$\begin{array}{l}\text { The annual } \\
\text { effective dose } \\
(\mathrm{mSv} / \mathrm{y})\end{array}$} & \multicolumn{3}{|c|}{ GRP with Permeability } \\
\hline & & & & & $10^{-11}$ & $10^{-12}$ & $10^{-13}$ \\
\hline 1 & 0.004326 & 0.006675 & 2.06 & 0.0195782 & 2.06 & 1.03 & 0.686666667 \\
\hline 2 & 0.008085 & 0.0124752 & 3.85 & 0.0365904 & 3.85 & 1.925 & 1.283333333 \\
\hline 3 & 0.00504 & 0.0077767 & 2.4 & 0.0228096 & 2.4 & 1.2 & 0.8 \\
\hline 4 & 0.002352 & 0.0036291 & 1.12 & 0.0106445 & 1.12 & 0.56 & 0.373333333 \\
\hline 5 & 0.005796 & 0.0089432 & 2.76 & 0.026231 & 2.76 & 1.38 & 0.92 \\
\hline 7 & 0.002709 & 0.00418 & 1.29 & 0.0122602 & 1.29 & 0.645 & 0.43 \\
\hline 8 & 0.010122 & 0.0156182 & 4.82 & 0.0458093 & 4.82 & 2.41 & 1.606666667 \\
\hline 9 & 0.014994 & 0.0231357 & 7.14 & 0.0678586 & 7.14 & 3.57 & 2.38 \\
\hline 10 & 0.014049 & 0.0216776 & 6.69 & 0.0635818 & 6.69 & 3.345 & 2.23 \\
\hline 11 & 0.012537 & 0.0193446 & 5.97 & 0.0567389 & 5.97 & 2.985 & 1.99 \\
\hline 12 & 0.002163 & 0.0033375 & 1.03 & 0.0097891 & 1.03 & 0.515 & 0.343333333 \\
\hline 13 & 0.00336 & 0.0051845 & 1.6 & 0.0152064 & 1.6 & 0.8 & 0.533333333 \\
\hline 15 & 0.007896 & 0.0121835 & 3.76 & 0.035735 & 3.76 & 1.88 & 1.253333333 \\
\hline 16 & 0.013335 & 0.0205759 & 6.35 & 0.0603504 & 6.35 & 3.175 & 2.116666667 \\
\hline 17 & 0.0018186 & 0.0028061 & 0.866 & 0.0082305 & 0.866 & 0.433 & 0.288666667 \\
\hline 18 & 0.002604 & 0.004018 & 1.24 & 0.011785 & 1.24 & 0.62 & 0.413333333 \\
\hline 19 & 0.0336084 & 0.0518578 & 16.004 & 0.152102 & 16.004 & 8.002 & 5.334666667 \\
\hline Min & 0.0018186 & 0.002806 & 0.866 & 0.0082305 & 0.866 & 0.433 & 0.288666667 \\
\hline Max & 0.0336084 & 0.0518578 & 16.004 & 0.152102 & 16.004 & 8.002 & 5.334666667 \\
\hline Average & 0.008629688 & 0.012630342 & 3.897894737 & 0.037045595 & 3.897894737 & 0.433 & 0.288666667 \\
\hline
\end{tabular}

As we can see in table 2 the values of geogenic radon potential (GRP) was calculated using Eq.5. The highest values of the (GRP) was found in Ishtar \Alttakhi School which is (16.004) with permeability $\left(10^{-11}\right)$ and the lowest value was found near Alaibtihal School which is $(0.288666667)$ with permeability $\left(10^{-13}\right)$. Based on many years of extensive research in the Czech Republic, three categories of GRP were set: low (GRP $<10)$, medium $(10<$ GRP $<35)$ and high $(35<$ GRP) [15], so all values of GRP are classified under the areas that have low GRP except for Ishtar \Alttakhi school which classified under the areas that have medium GRP. According to Barnet and Pacherová [18] low GRP causes $<230 \mathrm{~Bq} \mathrm{~m}^{-3}$, medium GRP causes $230-460$ $\mathrm{Bq} \mathrm{m} \mathrm{m}^{-3}$, high GRP causes $>460 \mathrm{~Bq} \mathrm{~m} \mathrm{~m}^{-3}$ indoor radon 
concentration, since the action level for IAEA (International Atomic Energy Agency) which is $\left(1000 \mathrm{~Bq} / \mathrm{m}^{3}\right)$ as a yearly average concentration for indoor radon in workplaces and Based on our results of GRP, all the chosen location are safe enough to categorize them under low radon risk areas.

\section{Conclusion}

From the present work, we can conclude:

All the results of radon concentrations were obtained in this study are well below the allowed levels which is range from $(0.4$ to 40$) \mathrm{KBq} / \mathrm{m}^{3}$. From the soil radon activity it has been able to calculate the Production rate (a) of emanation in soil, the Exhalation rate (E) and the radon activity of emanation in air near the ground. The annual effective dose that has been calculated from the Rn activity of emanation in air near the ground were less than the recommended global average dose from the inhalation of radon from all sources, which is $1 \mathrm{mSv} / \mathrm{y}$.

From the values of the geogenic radon potential (GRP) that has been calculated, we predicted the indoor radon concentrations which was less than the yearly average concentration for indoor radon in workplaces $\left(1000 \mathrm{~Bq} / \mathrm{m}^{3}\right)$, by using Barnet and Pacherová classification and based on that all the chosen location are safe enough to categorize them under low radon risk areas.

\section{References}

[1] G. Cinelli, L. Tositti, B. Capaccioni, E. Brattich, D. Mostacci. Environ Geochem Health. 2015; 37(2): 305-319.

[2] UNSCEAR, "Sources and Effects of Ionizing Radiation", Report to the general Assembly, UN, New York, 1993.

[3] Keith S, Doyle JR, Harper C, et al. Toxicological Profile for Radon. Atlanta (GA): Agency for Toxic Substances and Disease Registry (US); 2012 May.

[4] IARC Working Group on the Evaluation of Carcinogenic Risk to Humans. Lyon (FR): International Agency for Research on Cancer; Ionizing Radiation, Part2: Some Internally Deposited Radionuclides. IARC Monographs the Evaluation of Carcinogeni Risks to Humans, No. 78. 2001.

[5] National Research Council (US) Committee on Health Risks of Exposure to Radon (BEIR VI). Health Effects of Exposure to Radon: BEIR VI. Washington (DC): National Academies Press (US); 1999.

[6] Dr. khalid H. Mahdi, Dr. yousif M. Z. Al-Bakhat, Hadeel G. Ishnayyin. Advances in physics theories and applications journal, vol.35, 2014.k.
[7] Yousif M. zayir, Nada. S. Ahmedzeki, Takrid M. Nafae, Wssam Zaidan, O. El Samad and Rola Bou khozam. Iraq journal of chemical and petroleum Engineering. Vol. 17 No.2 (June 2016) 25-35.

[8] Jeff J. Danneels, Roger Coates, John R. Cochran, Dr. Ronald K. Chesser, Dr. Carleton J. Phillips. Proceedings of the 11th International Conference on Environmental Remediation and Radioactive Waste Management.September 2-6, 2007, Oud Sint-Jan Hospital Conference Center, Bruges, Belgium.

[9] Durridge Company Inc., Reference Manual version 6.0.1, RAD-7 ${ }^{\text {TM }}$ Electronic Radon Detector, (2010).

[10] SALONEN, L. 238U series radionuclides as a source of increased radioactivity in groundwater originating from Finnish bedrock. In: Proceedings of Future Groundwater Resources at Risk, Helsinki, June 1994, pp. 71-84. Wallingford, Great Britain Institute of Hydrology, 1994 (International Association of Hydrological Sciences Publication No. 222).

[11] HUBBARD, L. ET AL. Radon dynamics in Swedish dwellings: a status report. In: Proceedings of the 1991 International Symposium on Radon and Radon Reduction Technology, Philadelphia, Vol. 3, paper V-4. Research Triangle Park, NC, US Environmental Protection Agency, 1991.

[12] Moed, B. a., naZaroff, w. w., sextro, r. g., radon and its decay products in indoor air (naZaroff, w.w., nero Jr., a. V., eds), John wiley and sons, new York (1988) 57-112.

[13] Christain E. Junge, "Air Chemistry and Radioactivity", International Geophysics Series, Vol.4, 1963, p.209-220.

[14] V Gruber, P Bossew, M. De Cortl and T. Tollefsen, J. Radiol. Prot. 33 (2013) 51-60.

[15] Neznal, M., Neznal, M., Matolin, M., Barnet, I., Miksova, J. Czech Geol. Survey Special Papers, (2004) 16, 47 p.

[16] J. C. Baubron, A. Rigo and J. P. Toutain, The Jaunt Pass example (Pyrenees, France). Earth. Planet. Sci. Lett., 196(6981), (2002).

[17] G. Buttafuoco, A. Tallarico\& G. Falcone, Envir. Assess., 131 (2007) 135- 151.

[18] Barnet, I., Pacherová, P. In: Barnet, I., Neznal, M., Pacherová, P. (Eds.) Proc., 10th international workshop on the geological aspects of radon risk mapping. Czech geological survey, Radon v.o.s., Prague ISBN 978-80- 7075-754-3; (2010) 3541 .

[19] UNSCEAR. "Sources, effects and risks of ionizing radiation". United Nations Scientific Committee on the Effects of Atomic Radiation. Report to the General Assembly, United Nations, 2000, New York. 